\title{
Character Determination in Elementary School Children of Madrasah Ibtidaiyah Al Jamiyatul Washliyahin 2021 Based on the Fingerprint of Right Hands
}

\section{${ }^{1}$ Department of Forensic and Medicolegal Faculty of Medicine, University of Sumatera Utara}

Dewi Astuti Hasibuan ${ }^{1}$ | Asan Petrus ${ }^{*}$

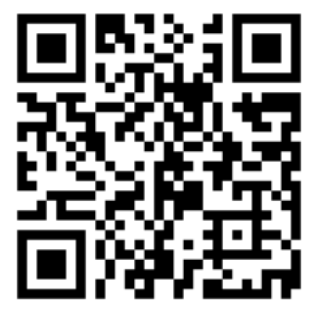

\begin{abstract}
Objective:To find out the character of elementary school students through fingerprint analysis. Method:This research is descriptive research. The research subjects were 43 students of Ibtidaiyah Al Jamiyatul Washliyah Elementary School in September 2021 until the number of samples was met. Student fingerprints are taken by placing the tips of the fingers on the stamp pads that have been given ink, then affixed to white paper to form fingerprints. This is done to completion on each student's right thumb. From the obtained fingerprints, direct observations were made on the fingerprint pattern (loop pattern, arch pattern, and whorl pattern). Collecting non-fingerprint data in the form of name and gender. Results:Get an effective learning system by getting to know the character of each student. Conclusion: Fingerprints can be used to identify students' characters. By getting to know the character of students, teachers can get to know better about students and create a better learning system. The frequency of Loop pattern fingerprints is more in women as much as $15(32.6 \%)$ than men as many as $6(13.04 \%)$ with a total The total Loop fingerprint pattern is 21 $(45.6 \%)$ and this is in accordance with the results of Galton's research which states that the Loop fingerprint pattern frequency is higher than the Whorl and

Keywords: fingerprint, personality, intelligence, character

Copyright : (C) 2021 The Authors. Published by Medical Editor and Educational Research Publishers Ltd. This is an open access article under the CC BY-NC-ND license (https://creativecommons.org/licenses/by-nc-nd/4.0/).
\end{abstract}

\section{1 | INTRODUCTION}

cience is growing rapidly and the various researches that have been carried out have given 
birth to new sciences. One of the sciences currently developing is dermatoglyphics. Dermatoglyphics is a branch of science that studies the indentations (lines) of the skin found on the fingers and toes in humans and other mammals (Reed \& Meier, 1990).

Fingerprints are one of the parts that are examined in dermatoglyphics. Fingerprints are images on the skin of the fingertips that are formed since the embryo and are maintained without changing. The picture of a fingerprint is typical for a person, because of the embodiment of the genes in him. This causes the fingerprint pattern to be used as a personal stamp[1] (Surjadi, et al., 1984).

Fingerprints are polygene inheritance. Based on the Galton system, fingerprints can be divided into 3 basic patterns, namely: arch or arch (A), figure or loop (L), and circle or whorl (W). The frequency of the presence of fingerprint patterns varies from finger to finger. The frequency of the loop fingerprint pattern is higher than the whorl and arch forms[2] .

Research researched by Iftita Candra Julida Errudyant, 2018 says that there is a relationship between the mathematical logical thinking ability of each student based on the similarity of fingerprint patterns and there are also differences in mathematical logical thinking abilities based on the type of fingerprint pattern.

The existence of a relationship between fingerprint patterns and a person's character gives rise to the idea of creating a system that can be used to analyze the characteristics of a child based on the type of fingerprint pattern they have.

Every child has different characteristics. These characteristics can arise due to external factors (environment), or can also come from internal factors (inheri-

Supplementary information The online version of this article (https://doi.org/10.52845/JMRHS/20214-11-5) contains supplementary material, which is available to authorized users.

Corresponding Author: Asan Petrus

Department of Forensic and Medicolegal Faculty of Medicine, University of Sumatera Utara tance). What is meant by characteristics derived from internal factors, namely, these characteristics are obtained from the inheritance of the characteristics of their parents which are carried through genes.

According to Misbach, 2010 each fingerprint reflects the uniqueness of each individual. There is no criterion that a certain type of fingerprint is a more ideal type of fingerprint compared to other fingerprints [3]. In fact, genetically, between one individual and another no one has the same fingerprint. These individual differences are called individual differences based on genetic inheritance to predict a person's behavior in the environment.

Fingerprint analysis is predictive, with the aim of providing an overview of why everyone is different in expressing their talents and interests, learning styles, capture power, thoroughness, to traits as the basis of one's personality (Misbach, 2010).

Future education will be able to produce more brilliant individuals if it is more focused on individual needs. Therefore, parents and educators are "suspicious" of seeing unusual behavior such as learning difficulties in children. If that happens the symptom needs to be viewed as a problem of unresolved needs that must be solved.

Based on the description and background above, I would like to conduct research to improve the quality of education for elementary school students, in addition to where the research has never been conducted before.

\section{Personality Type According to Fingerprint Pat- tern}

Each fingerprint pattern not only reflects their learning style, but also their personality type. The following is an explanation of how to recognize a child's personality with a fingerprint test or fingerprint pattern analysis:

\section{Whorl pattern fingerprint}

Fingerprintshows tend to be honest, critical, perfectionist, competitive, communicative, and strong willed.

\section{Loop pattern fingerprints}

Fingerprinttend to be serious and have high visual memory. 
3. Arch pattern fingerprints

Fingerprint Patternsshaped fingerprint patterns tend to hold traditional values and high morals, in other words they will retain traditional views about their own ambitions, careers, and leadership.

To conclude a person's innate character or character, it is best to look at the inner character, namely how the perspective is most important for him and how he makes decisions in the problems he faces.

\section{Research Methodology}

This research is a descriptive type of research with an analytical descriptive approach to the type of fingerprint data of SD Madrasah Ibtidaiyah Al Jamiyatul Washliyah students in 2021. The location of this research is SD Madrasah Ibtidaiyah Al Jamiyatul Washliyah, Jl. Cendrawasih, Sei Sikambing B, Medan Sunggal. Data collection for this study was carried out in September 2021 until the number of samples was met.

The population in this study were all elementary school students (SD) with a population of 74 people. In this study, researchers used a stratified random sampling technique for data collection. In this study, the samples taken were students of SD Madrasah Ibtidaiyah Al Jamiyatul Washliyah. The samplefor this study, the researcher will calculate using the Slovin formula as follows:

$\mathrm{n}=\mathrm{N}$

$1+\mathrm{N}\left(\mathrm{d}^{2}\right)$

$\mathrm{n}=74$

$\left.1+(74) \times 0,1^{2}\right)$

$\mathrm{n}=43$ people,

size based on the calculation of the formula above, in this study the minimum number of samples used was 43 people.

\section{RESEARCH RESULTS}

\section{2 | DESCRIPTION OF RESEARCH LOCATIONS}

Description of Research Location This research was conducted at the Elementary School (SD) Madrasah Ibtidaiyah Al Jamiyatul Washliyah Jl. Cendrawasih,
Sei Sikambing B Village, Medan Sunggal District. Student, Elementary School (SD) Al Jamiyatul Washliyah Elementary School in 2021 amounted to 74 students / I with the details of the male sex were 29 people and the rest of the women are 45 .

\section{3 | DESCRIPTION CHARACTERISTICS OF RESPONDENTS}

Description of the characteristics of respondents; The data obtained were based on self-measurement conducted by the researcher and under the supervision/guidance of the first and second supervisors. This study uses amethod stratified random sampling for data collection, and the number of samples taken using the Slovin formula, which after calculating the minimum sample size is 43 people, but in this study 46 people were taken so that the number of samples was sufficient to meet the research sample size.

Table 1: from the recap of the total number of respondents and fingerprint patterns of elementary school students at MadrasahIbtidaiyah Al Jamiyatul Washliyah.

\begin{tabular}{|c|c|c|l|l|c|c|c|c|c|}
\hline NUMBER & initial & gender & $\begin{array}{l}\text { age } \\
\text { (year) }\end{array}$ & FP & NUMBER & $\begin{array}{l}\text { initia } \\
\text { I }\end{array}$ & $\begin{array}{l}\text { gende } \\
\text { r }\end{array}$ & $\begin{array}{l}\text { age } \\
\text { (year) }\end{array}$ & FP \\
\hline 1 & $\mathrm{BA}$ & $\mathrm{L}$ & 10 & Arch & 24 & $\mathrm{Da}$ & $\mathrm{L}$ & 9 & Loop \\
\hline 2 & $\mathrm{Ke}$ & $\mathrm{L}$ & 10 & Loop & 25 & $\mathrm{Az}$ & $\mathrm{P}$ & 7 & Whorl \\
\hline 3 & $\mathrm{Mu}$ & $\mathrm{L}$ & 10 & Arch & 26 & $\mathrm{Dz}$ & $\mathrm{L}$ & 8 & Whorl \\
\hline 4 & $\mathrm{Ad}$ & $\mathrm{L}$ & 10 & Arch & 27 & $\mathrm{Sa}$ & $\mathrm{P}$ & 9 & Loop \\
\hline 5 & $\mathrm{Ha}$ & $\mathrm{L}$ & 10 & Arch & 28 & $\mathrm{Pu}$ & $\mathrm{P}$ & 10 & Loop \\
\hline 6 & $\mathrm{Mi}$ & $\mathrm{L}$ & 10 & Arch & 29 & $\mathrm{As}$ & $\mathrm{P}$ & 9 & Whorl \\
\hline 7 & $\mathrm{Al}$ & $\mathrm{L}$ & 10 & Arch & 30 & $\mathrm{Sa}$ & $\mathrm{P}$ & 12 & Loop \\
\hline 8 & $\mathrm{Fa}$ & $\mathrm{L}$ & 10 & Whorl & 31 & $\mathrm{Ca}$ & $\mathrm{P}$ & 10 & Whorl \\
\hline 9 & $\mathrm{Bi}$ & $\mathrm{L}$ & 11 & Arch & 32 & $\mathrm{Gi}$ & $\mathrm{P}$ & 7 & Loop \\
\hline 10 & $\mathrm{BS}$ & $\mathrm{L}$ & 9 & Loop & 33 & $\mathrm{Sy}$ & $\mathrm{P}$ & 8 & Whorl \\
\hline 11 & $\mathrm{FZ}$ & $\mathrm{P}$ & 9 & Arch & 34 & $\mathrm{Ak}$ & $\mathrm{P}$ & 9 & Arch \\
\hline 12 & $\mathrm{KA}$ & $\mathrm{P}$ & 10 & Arch & 35 & $\mathrm{Lu}$ & $\mathrm{P}$ & 8 & Whorl \\
\hline 13 & $\mathrm{MM}$ & $\mathrm{P}$ & 9 & Loop & 36 & $\mathrm{Az}$ & $\mathrm{P}$ & 8 & Loop \\
\hline 14 & $\mathrm{Ki}$ & $\mathrm{P}$ & 11 & Arch & 37 & $\mathrm{AS}$ & $\mathrm{P}$ & 9 & Loop \\
\hline 15 & $\mathrm{Va}$ & $\mathrm{P}$ & 11 & Arch & 38 & $\mathrm{Su}$ & $\mathrm{P}$ & 8 & Loop \\
\hline 16 & $\mathrm{Da}$ & $\mathrm{L}$ & 8 & Arch & 39 & $\mathrm{Li}$ & $\mathrm{P}$ & 10 & Whorl \\
\hline 17 & $\mathrm{AA}$ & $\mathrm{L}$ & 9 & Loop & 40 & $\mathrm{Iv}$ & $\mathrm{P}$ & 9 & Loop \\
\hline 18 & $\mathrm{Im}$ & $\mathrm{L}$ & 9 & Loop & 41 & $\mathrm{Ch}$ & $\mathrm{p}$ & 9 & Loop \\
\hline 19 & $\mathrm{Aw}$ & $\mathrm{L}$ & 10 & Whorl & 42 & $\mathrm{IH}$ & $\mathrm{P}$ & 11 & Loop \\
\hline 20 & $\mathrm{MA}$ & $\mathrm{L}$ & 9 & Whorl & 43 & $\mathrm{Fi}$ & $\mathrm{P}$ & 12 & Loop \\
\hline 21 & $\mathrm{LH}$ & $\mathrm{L}$ & 9 & Whorl & 44 & $\mathrm{Al}$ & $\mathrm{P}$ & 9 & Loop \\
\hline 22 & $\mathrm{Zi}$ & $\mathrm{L}$ & 11 & Whorl & 45 & $\mathrm{Ya}$ & $\mathrm{P}$ & 11 & Loop \\
\hline 23 & $\mathrm{Ad}$ & $\mathrm{L}$ & 10 & Loop & 46 & $\mathrm{Ak}$ & $\mathrm{P}$ & 7 & Loop \\
\hline
\end{tabular}

Notes: FP ; fingerprint pattern

Of the 46 total samples that participated in this study, there were 20 males ( $43.5 \%$ ), and 26 females $(56,5 \%)$. 


\section{Frequency Distribution by Gender.}

The number of respondents in this study were 46 people with the following characteristics.

Table 4.2 Characteristics of Research Respondents by Gender

\begin{tabular}{|l|c|c|}
\hline \multicolumn{1}{|c|}{ RESPONDEN } & TOTAL & PERCENTAGE \\
\hline MAN & 20 & $43,5 \%$ \\
\hline WOMAN & 26 & $56,5 \%$ \\
\hline TOTAL & 46 & $100 \%$ \\
\hline
\end{tabular}

Based on Table 4.2, it is known that there were 46 respondents with a male sex distribution of 20 $(43.5 \%)$, and 26 women $(56.5 \%)$.

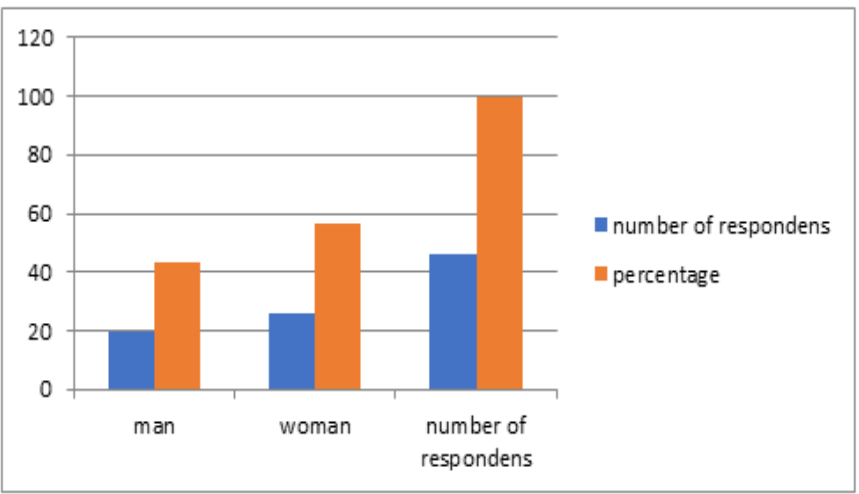

Figure 4.1 Block Diagram of Frequency Distribution by Gender

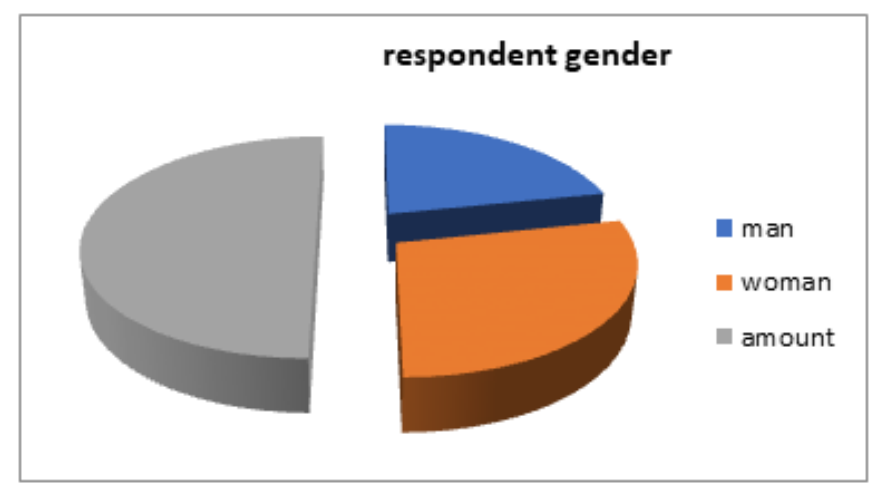

Figure 4.2 Pie Chart of Frequency Distribuon by Gender

Table 2 Frequency distribution based on fingerprint patterns by gender and the percentage of each fingerprint of elementary school students at Madrasah Ibtidaiyah Al Jamiyatul Washliyah in 2021seen

\begin{tabular}{|l|l|l|l|l|}
\hline fingerprint & man & Woman & TOTAL & PERCENTAGE \\
\hline Whorl & $6(13,04 \%)$ & $6(13,04 \%)$ & 12 & $26,1 \%$ \\
\hline Arch & $8(17,4 \%)$ & $5(10,9 \%)$ & 13 & $28,3 \%$ \\
\hline Loop & $6(13,04 \%)$ & $\mathbf{1 5}(32,6 \%)$ & 21 & $\mathbf{4 5 , 6 \%}$ \\
\hline Amount & 20 & 26 & 46 & $100 \%$ \\
\hline
\end{tabular}

From table 4.3 above it can beit was assessed that the frequency of Whorl fingerprints for men and women was the same, each 6(13.04\%), with the total number of respondents having Whorl fingerprints as many as $12(26.1 \%)$. The frequency of Arch pattern fingerprints was more in males as many as 8 $(17.4 \%)$ than females by $5(10.9 \%)$, with a total of 13 $(28.3 \%)$. The frequency of Loop pattern fingerprints is $15(32.6 \%)$ more in women than $6(13.04 \%)$ men with the total number of Loop pattern fingerprints 21 $(45.6 \%)$ and this is in accordance with the results Galton's research states that the Loop fingerprint pattern frequency is higher than the Whorl and Arch forms.

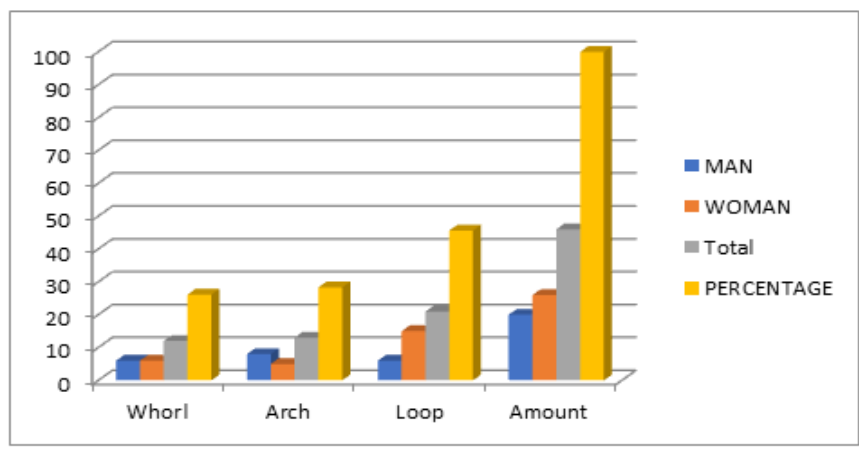

Figure 4.3 Diagram Frequency Distribution based on fingerprint pattern

Table 3 Character Distribution based on the fingerprint pattern group of each student of SD Madrasah Ibtidaiyah Al Jamiyatul Washliyah year 2021

\begin{tabular}{|c|c|c|}
\hline $\begin{array}{l}\text { Student group } \\
\text { (Initial) }\end{array}$ & Fingerprint & Character (Misbach,2010) \\
\hline $\begin{array}{l}\text { B, } \\
\text { A,MA,LH,Z,A,D } \\
\text {,A,C, S, L, L, }\end{array}$ & WHORL & $\begin{array}{l}\text { - Tend to be honest } \\
\text { - Critical } \\
\text { - Perfectionist (high ambitions } \\
\text { - } \text { towards the perfection of a work } \\
\text { - Competitive (high } \\
\text { - } \quad \text { Strongetitiveness) } \\
\text { - }\end{array}$ \\
\hline $\begin{array}{l}\mathrm{BA}, \mathrm{M}, \mathrm{A}, \mathrm{H}, \mathrm{M} \\
\mathrm{A}, \mathrm{B}, \mathrm{FZ}, \mathrm{KA} \\
\mathrm{K}, \mathrm{V}, \mathrm{D}, \mathrm{A}\end{array}$ & $\mathrm{ARCH}$ & $\begin{array}{l}\text { - Tend to hold traditional values } \\
\text { - High morals } \\
\text { - Traditional view of their own } \\
\text { ambition, career and leadership }\end{array}$ \\
\hline $\begin{array}{l}\mathrm{K}, \mathrm{BS}, \mathrm{MM}, \mathrm{AA}, \\
\mathrm{I}, \mathrm{A}, \mathrm{D}, \mathrm{S}, \mathrm{P}, \mathrm{S} \\
\mathrm{G}, \mathrm{A}, \mathrm{AS}, \mathrm{S}, \mathrm{I} \\
\mathrm{C}, \mathrm{IH}, \mathrm{F}, \mathrm{A}, \mathrm{Y}, \mathrm{A}\end{array}$ & LOOP & $\begin{array}{ll}\text { - } & \text { Tend to be serious } \\
\text { - } & \text { Have high visual memory }\end{array}$ \\
\hline
\end{tabular}


From table 4.4 Students with the initials: B, A, MA, LH, Z, A, D, A, C, S, L, L, have characters that tend to be honest, critical, perfectionist (high ambitions for the perfection of a work result). , Competitive (high competitiveness) and Strong willed, Students with the initials: BA, M, A, H, $\mathrm{M}, \mathrm{A}, \mathrm{B}, \mathrm{FZ}, \mathrm{KA}, \mathrm{K}, \mathrm{V}, \mathrm{D}, \mathrm{A}$, have characters who tend to hold values traditional, High morals, Traditional view of their own ambition, career and leadership, Students with initials: K, BS, MM, AA, I, A, D, S, P, S, G, A, AS, S, I, C, IH, F, A, $\mathrm{Y}, \mathrm{A}$ have characters who tend to be serious and have high visual memory.

\section{4 | DISCUSSION}

In this study, the data obtained were based on self-measurement conducted by the researcher and under the supervision/guidance of the first supervisor and second supervisor. This study uses amethod strat-ified random sampling for data collection, and the number of samples taken using the Slovin formula, which after calculating the minimum sample size is 43 people, but in this study 46 people were taken so that the number of samples was sufficient to meet the research sample size. Of the 46 total samples that participated in this study, there were 20 males (43.5\%), and 26 females (56.5\%).

From the results of this study, it can also be assessed that the frequency of Whorl pattern fingerprints for men and women is the same, each $6(13.04 \%)$, with the total number of respondents having Whorl pattern fingerprints as many as $12(26.1 \%)$. ). The frequency of Arch pattern fingerprints was more in males as many as $8(17.4 \%)$ than females by $5(10.9 \%)$, with a total of $13(28.3 \%)$. The frequency of Loop pattern fingerprints is $15(32.6 \%)$ more in women than $6(13.04 \%)$ men with the total number of Loop pattern fingerprints $21(45.6 \%)$ and this is in accordance with the results Galton's research states that the Loop fingerprint pattern frequency is higher than the Whorl and Arch forms.
Of all the students who were respondents in this study (46 people), the students with the initials: B, A, MA, LH, Z, A, D, A, C, S, L, L, had Whorl pattern fingerprints, which means has a character that tends to be honest, critical, perfectionist (high ambition for the perfection of a work result, competitive (high competitiveness) and strong willed, students with initials: BA, M, A, H, M, A, B, FZ, KA, K, V, D, A, have fingerprints with an Arch pattern, which means characters who tend to hold traditional values, high morals, traditional views about their own ambition, career and leadership, and students with the initials: $\mathrm{K}, \mathrm{BS}, \mathrm{MM}, \mathrm{AA}, \mathrm{I}, \mathrm{A}, \mathrm{D}, \mathrm{S}, \mathrm{P}, \mathrm{S}, \mathrm{G}, \mathrm{A}, \mathrm{AS}, \mathrm{S}, \mathrm{I}, \mathrm{C}$, IH, F, A, Y, A have fingerprints with a Loop pattern which means they have characters Tend to be serious and have high visual memory.

CONCLUSION Based on the results of research and data analysis in this study, it is concluded that:

1. Students with the initials: B, A, MA, LH, Z, A, D, A, C, S, L, L, have characters that tend to be honest, critical, perfectionist (high ambitions for the perfection of a work, competitive ( high competitiveness) and strong willed

2. Students with the initials: BA, M, A, H, M, A, B, FZ, KA, K, V, D, A, have characters who tend to hold traditional values, high morals, traditional views on ambition, career and their own leadership

3. Students with the initials: K, BS, MM, AA, I, A, D, S, P, S, G, A, AS, S, I, C, IH, F, A, Y, A have a character Tend to be serious and have a high visual memory.

4. Fingerprint frequency whorl patterns in men and women alike, each $6(13.04 \%)$, with the total number of respondents who have fingerprint whorl patterns were $12(26.1 \%)$. The frequency of Arch pattern fingerprints was more in males as many as 8 $(17.4 \%)$ than females by $5(10.9 \%)$, with a total of 13 (28.3\%). The frequency of Loop pattern fingerprints is $15(32.6 \%)$ more in women than $6(13.04 \%)$ men with the total number of Loop pattern fingerprints 21 $(45.6 \%)$ and this is in accordance with the results Galton's research states that the Loop fingerprint pattern frequency is higher than the Whorl and Arch forms. 


\section{I SUGGESTION ; BASED ON THE RESEARCH THAT HAS BEEN CARRIED OUT, THE RESEARCHERS SUGGEST:}

1. So that the results of this study can be used by the teachers of SD Madrasah Ibtidaiyah Al Jamiyatul Washliyah in guiding their students.

2. The results of this study can also be used by parents of elementary school students at Madrasah Ibtidaiyah Al Jamiyatul Washliyah in guiding their children.

\section{6 | REFERENCES}

Mandeep Singh, Oindri Majumdar, 2015. Dermatoglyphics: Blueprints of Human Cognition on Fingerprints

Ben Adrian, 2018, Amazing Finngerprint, mengungkap watak dan bakat

Misbach, 2010. Dahsyatnya Sidik Jari Menguak Bakat dan Potensi untuk Merancang Masa Depan Melalui Fingerprint Analysis

Cummins H.,"Finger Print, Palm and Soles An Introduction To Dermatoglyhics," The blakiston company, Philadelphia 1943.

Galton F., "Finger Prints," Macmillan, London 1892.

I Gede Sujana E. P., "Pengenalan Keperibadian Seseorang Berdasarkan Sisik Jari Dengan Metode Fuzzy Learning Vector Quantization Dan Fuzzy Backpropagation," vol. 13, no. 2 juli- desember 2014.

Ifa H. Misbach, Tim Psikobiometric Research. 2010. Dahsyatnya Sidik Jari Menguak Bakat \& Potensi Untuk Merangcang Masa Depan Melalui Fingerprint Analysis. Jakarta : Visi Media
Campbell, E.D. 2003. Biometrics Future \& Profit. http://stat.tamu.edu/Biometrics/28/04/2005. Diakses pada 07-12-2013

Surjadi, R Satmjoko, R, Rafiah R.S, Syahrum M.H dan Ramelan W, 1984. Pola Sidik Jari dan Total Ridge Count Kelompok Residivis di Indonesia. Majalah Kedokteran Indonesia. Vol. 34(3): 101-104.

Reed, T. dan Meier R., 1990. How To Take Dermatoglyphic Prints. The American Dermatoglyphic Association.

Syailendra, WS. 2011. Kajian Ilmiah Analisa Sidik Jari.

http://otaktengahindonesia.com/artikel_kajian-ilmia h-analisa-sidik-jari.html. Diakses 30-12-2013

Soma, I. G. 2002. Dermatoglifik sebagai Alat Diagnosa. Jurnal Veteriner. Vol. 3 (2) : 25- 28.

Poniman, F. 2011. Penjelasan Hasil Tes STIFIn. Bekasi: PT. STIFIn Fingerprint

Ziqrahaniffah, 2019, "Deteksi kepribadian anak dengan sidik jari menggunakan Metode K-Nearest Neighbor (KNN) dan Decision Tree" e-Proceeding of Engineering: Vol.6, No.2 Agustus 2019

Robert A. Rohm, "Who do you think you are anyway?", Personality Insights Incorporated, 1997

Gardner, Howard; Frames of Mind: The theory of multiple intelligences, New York: Basic Books, 1993

How to cite this article: Hasibuan D.A., Petrus A. Character Determination in Elementary School Children of Madrasah Ibtidaiyah Al Jamiyatul Washliyahin 2021 Based on the Fingerprint of Right Hands. Journal of Medical Research and Health Sciences. 2021;1545-1550. https://doi.org /10.52845/JMRHS/2021-4-11-5 